\title{
Negligence and the Infliction of Emotional Harm: A Reappraisal of the Nervous Shock Cases
}

Unlike physical harm, which results only from physical contact, emotional harm ${ }^{1}$ results from psychic reactions to stimuli from several senses, including sight and sound. Thus, while a person's careless conduct may physically injure only those in a prescribed zone of physical risk, it may emotionally injure a great many more. ${ }^{2}$ The reaction of the law to this expansive potential of emotional tort liability has been a subject of discussion in the literature since the turn of the century. ${ }^{3}$ The fact that so many courts have chosen to use arbitrary limitations - such as the traditional requirements of impact or that the defendant was in the zone of physical risk ${ }^{4}$-rather than a pure negli-

1 "Emotional harm," as used in this comment, refers to emotional injury which is serious enough to require medical attention. It includes many reactions which might be described as physical, such as shock and illness. See text accompanying notes 27-28 and 63.67 infra.

2 The victim of emotional injury need not be a participant in an accident; he may be upset by seeing or hearing about it.

3 For a compilation of the many important articles and authorities, see C. GREGoRY \& H. Kalven, Cases and Materials on Torts 883 n.8 (1959). Recent articles of general interest are Havard, Reasonable Foresight of Nervous Shock, 19 MoD. L. Rev. 478 (1956), and Rendall, Nervous Shock and Tortious Liability, 2 OsGoode Haxl L. REv. 291 (1962).

4 These limitations took the form of an element the plaintiff had to establish in addition to causation and negligence. At first this element was physical impact. This was broadened by the superseding requirement that the defendant's conduct must have placed the plaintiff in a hypothetical zone of physical risk. Now many courts talk in terms of foreseeability of emotional harm, although the bounds of foreseeability seem suspiciously like those of the zone of physical risk.

To recover for shock under the impact rule, the plaintiff had to show that the defendant had struck him. See, e.g., Mitchell v. Rochester Ry. Co., 151 N.X. 107, 45 N.E. 354 (1896). Plaintiff sued for nervous shock after defendant's team of horses trotted toward her, stopping only when she was between their heads. Since the horses did not touch her and thus did not physically harm her, she could not recover.

The impact requirement was originally designed to guarantee that the plaintiff had good reason to have been shocked. It was "not a product of the liability formula, or a logical deduction from principles of tort law, but rather a child of administrative expediency." Smith, Relation of Emotions to Injury and Disease: Legal Liability for Psychic Stimuli, 30 VA. L. REv. 193, 232 (1944).

Following the trend established by a majority of jurisdictions, the New York Court of Appeals finally overruled Mitchell $v$. Rochester in Battalla v. State, 10 N.Y.2d 237, 219 N.Y.S.2d 34, 176 N.E.2d 729 (1961), in which a child who had been improperly secured in a chair lift at a ski resort recovered for her fright despite the absence of impact. 
gence analysis to regulate liability has often troubled the leading authorities, ${ }^{5}$ but none has attempted to determine how a negligence approach might work.

Three recent American cases highlight the utility of a negligence approach. The first two involve rather bizarre psychological responses to seemingly commonplace traffic accidents: in each the defendant carelessly drove out of a side street and bumped the rear of the plaintiff's vehicle. The impact was slight; there were no physical injuries and less than $\$ 100$ property damage. Yet soon afterward the plaintiff developed neurotic symptoms.

In Williamson $v$. Bennett ${ }^{6}$ the plaintiff's psychiatrist testified that her neurosis ${ }^{7}$ was precipitated by her imagining at the moment of impact that a little girl had been killed by bicycling into the back of her car. About a month earlier a girl had in fact killed herself by bicycling into the car of plaintiff's brother-in-law. It was the superimposition of her recollection of this dreadful event upon her perception (or lack thereof) of the accident scene that led to her psychic reaction.

See W. Prosser, TORTS 350-51 (3d ed. 1964) [hereinafter cited as Prosser], for cases in other jurisdictions undermining the impact requirement by finding impacts of a most trivial nature.

Under the zone of physical risk theory, the defendant was held liable for breach of a duty to the plaintiff not to place him in physical danger. The plaintiff was allowed to recover for the emotional consequences of this breach. For discussion and criticism of this theory, see Goodhart, The Shock Cases and the Area of Risk, 16 Mod. L. REv. 14 (1953), and Rendall, supra note 3, at 315. See also notes 40-41 \& 47-50 and accompanying text infra.

For a discussion of the "foreseeability" test to which the British courts have recently turned, see the text accompanying notes 53-56 infra. In King v. Phillips, [1953] I Q.B. 429 , the court found unforeesable the emotional harm suffered by a mother who, at a safe distance from the accident, watched a cab strike her child. This result is identical with those reached in Waube v. Warrington, 216 Wis. 603, 258 N.W. 497 (1935), and Resavage v. Davies, 199 Md. 479, 86 A.2d 879 (1952), classic American cases decided under a zone of physical risk analysis.

5 Professors Harper and James submit, for instance, that: "[T]hese questions will be solved most justly by applying general principles of duty and negligence, and that mechanical rules of thumb which are at variance with these principles do more harm than good." 2 F. FARPER \& F. JAMES, ToRTS 1039 (1956) [hereinafter cited as HARPER \& JAMES].

6 251 N.C. 498 , 112 S.E.2d 48 (1960).

7 The psychiatrist diagnosed her condition as a "conversion reaction," a reaction which occurs when emotional and psychological upset, nervousness, and anxiety are so intense that the mind and body convert them into a physical symptom. Parts of plaintiff's body had become numb or paralyzed a few days after the accident. The psychiatrist described the conversion reaction as a "post traumatic neurosis"; he also testified that, prior to the accident, the plaintiff was unusually susceptible to neurotic difficulties, due to certain childhood experiences. 251 N.C. at 501, 112 S.E.2d at 50. 
In Kaufman v. Miller ${ }^{8}$ the victim's psychiatrist linked his reaction ${ }^{9}$ to an accident which had occurred two years before. At that time his truck had jack-knifed and started a fire which killed three people. He had become extremely fearful of hurting people while he was driving-by nature, he was what psychiatrists call a "passive dependent."10 When he realized that he had been unable to avoid another accident, his fears overwhelmed him; he became neurotic.

Given the precedents, these two plaintiffs should have recovered.11 The defendants were unquestionably negligent in causing impact and creating physical risk for the plaintiffs, thereby satisfying the two traditional tests. Yet both courts denied recovery upon two grounds. First, they analogized the plaintiffs to bystanders on the theory that the plaintiffs suffered their injuries from worrying about the safety of third persons. ${ }^{12}$ Second, they stated that, given the accident situation, no one could have foreseen emotional injury to a normal victim. ${ }^{13}$

Technically, the comparison of the plaintiffs to bystanders was a poor one. Previous courts had precluded bystanders from recovering because they were outside the zone of physical risk, and not because they worried about the safety of third persons. ${ }^{14}$ Here both plaintiffs were actually hit.

8414 S.W.2d 164 (Tex. 1967).

P Plaintiff began to suffer from dizziness and blackouts after the accident; this forced him to give up truck driving. Later, he experienced frequent nausea and nightmares. His psychiatrist attributed his difficulties to a conversion reaction neurosis which followed the accident. 414 S.W.2d at 166-67.

10 Plaintiff's psychiatrist defined a passive dependent personality as one which is "characterized by helplessness, indecisiveness, and a tendency to cling to others. . . . These individuals must, at all costs, conceal their energy and aggressive impulses from their own consciousness. ... These are nice, quiet, gentle people, who would never hurt a fly. For such a person hurting a fly, without intending, and without any way of not inflicting the damage or hurting, is a frightening experience." It was his opinion that passive dependents are more susceptible than ordinary people to developing conversion reactions. Id.

11 Courts have often attached recovery for emotional injury onto a cause of action for a physical tort, holding that a defendant is liable for all the consequences of his original breach of duty to the plaintiff. In Williamson and Kaufman, the defendants committed a tort when they carelessly bumped the plaintiff's cars. For an application of this reasoning, see the discussion of Schneider v. Eisovitch, [1960] 2 W.L.R. 169, in text accompanying note 38 infra.

12 Williamson v. Bennett, 251 N.C. at 508, 112 S.E.2d at 55; Kaufman v. Miller, 414 S.W.2d at $168-69$.

13 Williamson v. Bennett, 251 N.C. at 508,112 S.E.2d at 55; Kaufman v. Miller, 414 S.W.2d at 167 .

14 The leading American case is Waube v. Warrington, 216 Wis. 603, 258 N.W. 497 (1935). A mother had died of shock after witnessing the defendant run over her child. The court applied a zone of physical risk analysis to deny recovery.

Courts following the Waube case have interpreted it to mean that one could not recover if his shock was caused by fear for the well-being or safety of another. This is an 
The better and more significant ground for these decisions is the foreseeability analysis. The courts here were drawing an important distinction between risk of physical injury, clearly present in these cases, and risk of emotional injury. Distinct requirements of foreseeability were imposed as to each of these qualitatively different risks. ${ }^{15}$

In the third case, Mason $v$. Gray, ${ }^{16}$ the defendant's carelessly parked car started to roll down a hill toward the plaintiff's infant child, who was lying on the grass in a bassinet. The plaintiff heard the car coming and made a dash to save her baby, but fell on the way. She suffered shock and continued nervousness after the child was hit.

Under traditional approaches, she had no cause of action, since she was neither hit nor subjected to any physical risk. ${ }^{17}$ Yet the trial judge dismissed defendant's motion for summary judgment. In so doing, he made an eloquent plea for protection of the mind and emotions by the tort law:

[T]he orderly and normal functions of man's mind and emotions are as vital to his efficient operation as his legs, hands, eyes or ears .... [ [P]eople are as entitled to be free from psychotic scars upon the mental functions as they are to be free from scars upon their body. Indeed, protection of the mind may be of greater importance than protection of the mechanical functioning of the body. We need only look at the world around us to observe that healthy minds linked with disabled bodies can accomplish much, while sick minds in the strongest of physical structures will contribute nothing to the welfare of the individual or society. ${ }^{18}$

$\mathrm{He}$ also systematically rejected as inconsistent all theories which

obvious misinterpretation of its holding, but one which has persisted. Cf. Hambrook $\mathrm{v}$. Stokes Bros., [1925] I K.B. 141; and Bowman v. Williams, 164 Md. 397, 165 A. 182 (1933), which allowed plaintiffs who worried about the safety of their children to recover because they were in the zone of physical risk. See text accompanying notes 40 \& 41 infra.

For a listing of cases which accept or reject this limitation, see Comment, TortsNegligently Induced Fright Causing Physical Injury to Hypersensitive Plaintiff, 39 N. CAr. L. Rev. 303, 306 n.26 (1961). See also Prosser 352-54, and text accompanying notes 42-44 infra.

15 This necessarily. repudiates the theory that any initial breach of duty leads to recovery for all the consequences. To recover for emotional harm which is unrelated to physical injuries, the plaintiff must prove an emotional tort.

It should be noted that in result rather than reasoning, the courts imposed a foreseeability test in addition to the traditional ones, requiring that both be satisfied before the plaintiffs could recover. They did not, on the facts of the cases, have to decide whether foreseeability should be imposed instead of the traditional tests.

16 Case No. 22544 (Kootenai County Ct. Idaho, filed Sept. 26, 1967). See also Tobin v. Grossman, 284 N.Y.S.2d 997 (Sup. Ct. 1967).

17 See note 4 supra.

18 Mason v. Gray, Case No. 22544 at 5 (Kootenai County Ct. Idaho, filed Sept. 26, 1967). 
might tack the plaintiff's recovery onto a cause of action for a physical tort, ${ }^{19}$ placing liability squarely upon the existence of an emotional tort:

... a mother who witnesses her infant child being overrun by a defendant's negligently operated automobile, while not in fear for her own safety and not herself struck, may recover for the resulting emotional shock, fright, and nervousness, shown by a preponderance of the evidence to have proximately resulted therefrom. ${ }^{20}$

Williamson, Kaufman, and Mason illustrate the limitations of the traditional tests, which have served reasonably well to deal with accidents in which the defendant's conduct created a risk of both physical and emotional injury. The deficiency of these tests is that they do not take into account the fact that a defendant's conduct may create serious risk of physical injury without risk of emotional injury in the normal victim, and vice versa. Hence, in cases like Williamson and Kaufman, liability might sweep too broadly. Yet, for the mother in Mason, liability is not broad enough. The choice of a limiting factor in the traditional tests is too arbitrary to supply the courts with a consistently just formula.

This comment will examine what a pure negligence approach might look like in practical application, comparing the results of such an approach to those obtained under traditional tests.21

A negligence approach for emotional torts was first advocated by Dr. Hubert Smith in his celebrated study of psychic injury.22 Dr. Smith proposed that, in emotional injury cases, negligence be determined by the risk of emotional harm created by defendant's conduct. Liability would be predicated on a finding that the defendant's conduct caused a substantial and unreasonable risk of emotional harm to a normal person in the plaintiff's position. ${ }^{23}$

Standing alone, this formula gives a jury little guidance for determining whether a defendant is liable. To what kinds of injury does "emotional harm" refer? Of what harm must there have been a risk-

19 E.g., damage to her bassinet.

20 Mason v. Gray, note 18 supra, at 19-20.

21 Except for comparative purposes, the intentional infliction of emotional harm will not be discussed. See note 60 infra.

22 See Smith, supra note 4.

23 Id. at 242. 
the harm that befell the plaintiff or emotional harm in general? And what is a "normal person in the plaintiff's position?"

The legal definition of "emotional harm" largely determines the scope of emotional tort liability, a fact which traditional theory has implicitly recognized. ${ }^{24}$ A broad definition of "emotional harm"-one which includes upset, anger, and grief-would make it easy to establish a "threshold tort." ${ }^{25}$ A very narrow definition-one which requires permanent emotional injury-would make it virtually impossible to establish the threshold tort, for psychic stimuli rarely if ever cause permanent damage in normal individuals. ${ }^{26}$ The difficulty of defining the "emotional harm" necessary to establish a threshold tort in a way which produces results somewhere between the Scylla of unlimited liability and the Charybdis of no liability has probably been a primary factor in discouraging attempts to utilize the negligence approach in emotional injury cases.

The necessary middle ground lies in a definition of "emotional harm" which excludes mere upset, dismay, humiliation, grief, and anger. ${ }^{27}$ If one person's careless conduct causes another to experience such emotions, this conduct has not harmed him in a way which justifies the imposition of liability. Even aside from the problem of unlimited liability, it is unreasonable to require that people act so carefully as to avoid occasionally angering or upsetting others, just as it is unreasonable to demand that one never accidentally jostle another in a crowd.

What "harm," then, is necessary to support a threshold tort? One example is "shock" - the sudden agitation of the mental senses which temporarily incapacitates the victim and requires at least minimum medical attention. Other examples are continuing nervousness, sleeplessness, or nausea for which a physician would prescribe medication. Beyond this threshold are the neuroses, resulting psychosomatic disabilities, and other more serious illnesses. "Harm," then, is mental distress serious enough to require medical attention. ${ }^{28}$

24 See discussion of the Restatement definition at text accompanying notes 65-67 infra. Although traditional theory has concentrated upon physical limitations, Professors Harper and James prefer a formula which requires risk of "injury" to a "normal" person. "There is good reason to believe that this rational test would be hard enough to meet according to currently accepted medical notions ..." HARPER \& JAMES 1036.

25 "Threshold tort" here refers to the minimum requirements for establishing a defendant's liability.

26 Havard, supra note 3, at 482.

27 For example, if grief were "emotional harm," then Lee Harvey Oswald committed millions of emotional torts when (and if) he killed President Kennedy, for it was foreseeable that such an action would bring sorrow to millions of normal people the world over.

28 The "medical attention" in this minimum standard refers to any kind of aid, consultation, or prescription, and not just psychiatric help. Admittedly this standard 
In its calculus of risk, a negligence formula operates correctly only if foreseeability refers to the possibility of harm in general, and not to the possibility of the specific injury which befell the plaintiff. ${ }^{29}$ This applies equally to physical and emotional torts.

This proposition is most readily understood in the context of physical injury cases, where it is easy to perceive the possibility of injury at the point of contact. Thus if $D$ carelessly smashes into $P$ 's car, one inquires whether or not $P$ might be hurt, not whether or not $P$ would be thrown through the windshield, flip three times in the air, and land upon his head, if that is what actually happened. If the law demanded that the latter be foreseeable in order that $D$ be held liable, $P$ 's chances of recovery would be greatly reduced.

In emotional injury cases the existence of harm is often not apparent until the victim's specific reaction is discovered. There is nothing comparable to the collision which is observable. The jury might be tempted, then, to concentrate upon the specific reaction when applying the foreseeability test. Unless the courts, through careful instructions, force the jury to resist this temptation, the negligence approach will break down.

The designation of a "normal person in the plaintiff's position" as the standard against which the defendant's conduct is measured is necessary if too great a burden of care is not to be placed upon the individual in pursuit of his everyday affairs. It seems most reasonable to let people assume that those with whom they have contact are emotionally normal, unless they know or should have known otherwise. The greater protection a stricter standard might afford would be more than offset by the resulting flood of trivial cases.

The law applies the same standard in the physical injury fieldpeople do not have to treat others as if they had thin skulls, were hemophiliacs, etc., unless they are aware of such disabilities. Otherwise, people could not touch each other. Once a person becomes aware of another's disability, either physical or emotional, it is reasonable to ask that he be more careful toward him. ${ }^{30}$

is rather vague; but "harm" is not a concept which can be defined with precision. See text accompanying notes 68-69 infra for a discussion of the difficulty to which this vagueness may lead.

29 Rendall, supra note 3, at 316-17. Smith agrees, pointing out that foreseeability must not be aplied to the exact mechanism by which the injurious psychic stimulus caused harm, Smith, supra note 4, at 242.

30 As long as he can show that the defendant's conduct created a substantial and unreasonable risk of "emotional harm" to a normal person, the abnormal or idiosyncratic plaintiff can recover as well as the normal one, even if his injury is more serious than the one a normal victim probably would have received. If the defendant knew of 
One must not confuse the standard of liability with the extent of recovery once liability is established. As to the latter, the so-called "thin skull rule"31 may apply so that the victim recovers to the full extent of his injuries.32 "You take your victim as you find him."

Normality is both a statistical and a medical concept. It is directed toward the range of individuals whose emotional makeup may be described as lying within a curve which statisticians define as representing the normal. It is not exactly an average, for there is normality on both sides of the midpoint of the curve. It is not representative of the way psychiatrists sometimes use the word to refer to a hypothetical perfect individual, always well-balanced, neither too optimistic nor too pessimistic, etc. Such an individual does not exist and is an absurd standard of reasonableness of conduct.

Admittedly, no one has compiled data which indicate how most people react to accidental stress situations, although battlefield studies indicate that human tolerance of stress is fairly high.33 Until such knowledge is acquired, the jury will have to rely upon its own estimate to determine the standard of normality.

Creating a certain degree of tension with the standard of normality

plaintiff's peculiarity, the idiosyncratic plaintiff need only show that the defendant's conduct created a substantial and unreasonable risk of harming him.

At least one commentator has argued that idiosyncratic plaintiffs should not recover at all. But he did so in the context of a discussion of Williamson v. Bennett, 251 N.C. 498, 112 S.E.2d 48 (1960), arguing that there would have been no injury if the plaintiff had not been idiosyncratic. 43 N. CAR. L. REv. 1011, 1016 (1965).

Under a negligence approach, the case of an idiosyncratic plaintiff cannot depend upon his peculiarity, since liability is predicated upon the possibility of injury to a normal person. Where injury does depend upon his peculiarity, as in Williamson, he may not recover.

31 This rule derives its name from a reference by Kennedy, J., in Dulieu v. White \& Sons, [1901] 2 K.B. 669, 679, one of the earlier nervous shock cases. If plaintiff can establish that defendant has negligently fractured his thin skull, he may recover for all the resulting damage, even if a normal person would not have been so badly hurt.

32 Theoretically, in a case involving a victim with a special susceptibility to harm: "The measure of damages, as determined by a jury under a proper charge, consists of subtracting the condition which would have resulted in any event because of the weakened condition of the plaintiff from the condition which exists after the accident." Comment, Measure of Damages-Aggravation of Previous Injury, Disease, Disability or Latent Weakness, 22 ST. JoHN's L. REv. 135, 137 (1947). This formula has been successfully administered in physical injury cases. Is it of similar utility for emotional injuries?

Before psychiatric testimony was readily accepted, this created a difficult problem for the courts. However, the depth and expertise of the psychiatric testimony in cases like Williamson and Kaufman indicate that today the problem of proof is no longer insurmountable. Causation may be fixed and the injury apportioned if courts insist upon a thorough inquiry into the victim's pre- and post-accident mental state. After such a thorough inquiry, there is little reason to fear that the jury may somehow fail to assess damages as "accurately" as it might in a physical injury case.

33 For a medically oriented discussion of stress, see Havard, supra note 3, at 478-83. 
is the equally significant concept "in the plaintiff's position." The jury will not estimate the risk created by the defendant's conduct in a vacuum, but against the situation in which the victim was placed. "In the plaintiff's position" contains three major variables, all relating to proximity: physical proximity, temporal proximity, and proximity of relationship. ${ }^{34}$

It would seem that the nearer the victim is to the upsetting conduct, the more likely he is to become upset. As Dr. John Havard has argued, the strongest fear is one of personal destruction; this arises only when life and limb are endangered. ${ }^{35}$ The greater the fear, the more likely the harm. A continuum develops based on the variables of time and physical location-one is more likely to suffer from a near miss than from hearing about an accident a few days after it occurred. The bystander, then, is less likely to be emotionally injured than the participant.

It would also seem that the closer the relationship between a person observing or hearing about an accident and the victim, the greater the probability that the witness will experience a serious emotional reaction. Thus a mother watching her child get run over is more likely to suffer emotional harm than is someone who did not even know the victim. ${ }^{36}$

The jury will undoubtedly have to give lesser consideration to minor variables, including age and sex, in its estimation of normal reactions. For instance, it might reasonably expect a stronger reaction from a young girl or an old lady than from a middle-aged man. The jury, however, must not take into consideration any of the plaintiff's emotional idiosyncracies. Pushed to such an extreme, the concept of "in the plaintiff's position" would swallow up its parent concept, normality, rather than functioning as a qualifying principle.

These observations about "emotional harm," specificity of risk, and a "normal person in the plaintiff's position" provide functional guidelines for jury instructions. By setting standards of harm and normality against which the jury can measure risk, they help solve the problem of limitation. By demanding that risk be calculated according to the

34 Dean Prosser suggests the factors which follow, not as variables, but as limitations. Prosser 354. Unfortunately, he sees these limitations as entirely arbitrary, a conclusion with which this author respectfully disagrees. Within the context of a risk analysis, they make sense, as the text following this note indicates.

35 Havard, supra note 3 , at 482 . This is the reason, of course, that most emotional injury cases involve both emotional and physical risk.

36 The two variables combine rather strikingly in Hambrook v. Stokes Bros., [1925] I K.B. 141, the runaway lorry case, in which the mother feared both for her life and for the safety of her children. By contrast, one does not expect the reader, removed by years, miles, and relationship from the experience to get upset by the case. 
hypothetical reactions of a normal person rather than the particular reactions of the victim, they provide as well a rational basis for handling the problem of the idiosyncratic plaintiff.

\section{II}

An examination of the leading emotional injury cases makes it possible to compare the current law with the potential result, if not the rhetoric, of a negligence approach. These cases may be divided into: (1) those in which the plaintiff is physically hit; (2) those in which the plaintiff is in the zone of physical risk; (3) those in which the plaintiff is a bystander; and (4) those in which the plaintiff is not at the scene of the accident.

Physical impact. Plaintiffs first recovered damages for emotional injury when they had been physically struck as a result of the defendant's conduct. Such damages have been labeled "parasitic" because of the way they attached themselves to recovery for physical injury. ${ }^{37}$ The theory was that once the defendant had been negligent toward the plaintiff in a physical sense, he was liable for all the consequences, be they physical or emotional.

Such a theory can lead to bizarre results, as the court's reasoning in the recent British case of Schneider $v$. Eisovitch ${ }^{38}$ illustrates. The plaintiff and her husband were passengers in the auto of the defendant when he carelessly caused an accident. The plaintiff was rendered unconscious and her husband instantly killed. She did not recover consciousness until after she reached a hospital. Her physical injuries were slight, but upon learning of her husband's death, she suffered shock. Her psychic difficulties remained after she was released from the hospital.

The relevant issue was whether or not the plaintiff could recover for the shock she received when she learned of her husband's death. The court reasoned that since the defendant breached a duty to the plaintiff by injuring her, and since the plaintiff would not have heard of her husband's death except for the accident (which was the breach), the defendant was liable, despite the time lapse:

The fact that the defendant by his negligence caused the death of the plaintiff's husband does not give the plaintiff a cause of action for the shock caused to her; but the plaintiff, having a cause of action for the negligence of the defendant, may add the consequences of shock caused by hearing of her 
husband's death when estimating the amount recoverable on her cause of action. ${ }^{39}$

The plaintiffs in Williamson and Kaufman would have recovered if the courts had reasoned this way, for the defendants in those cases were unquestionably physically negligent in causing a collision. The result in Schneider does not, of course, seem strange. But what should the result have been if the person who had been killed had been a total stranger to the plaintiff? Under the court's reasoning, since the defendant had been physically negligent toward the plaintiff, she could still recover. Smith's negligence approach distinguishes between the two types of situations, while traditional theory does not.

Zone of physical risk. Hambrook v. Stokes Brothers ${ }^{40}$ and Bowman v. Williams $s^{41}$ are the British and American cases most frequently cited in support of a "zone of physical risk" concept. In Hambrook the defendant had carelessly left his lorry so that it rolled down a hill toward the plaintiff and her children. Plaintiff suffered shock from fear that she or her children might be hit. In Bowman a father suffered shock after watching the defendant's truck crash into his house beneath the room where he stood, while his children were in the basement. The shock allegedly resulted from fear for them, rather than fear for himself.

Both courts founded liability on the ground that the defendants had breached a duty toward the plaintiffs by carelessly letting their trucks roll in the plaintiffs' direction. The plaintiffs could recover for all the consequences of this breach.

The defendants had attempted to defend upon what has become known as "Kennedy, J's limitation," put forth in Dulieu $v$. White \& Sons, ${ }^{42}$ that the shock must be caused by fear for one's own safety and not that of another. Both courts rejected this dictum. ${ }^{43}$ They saw no

39 Id. at 177.

40 [1925] 1 K.B. 141 (1924).

41164 Md. 397, 165 A. 182 (1933).

42 "It is not, however, to be taken that in my view every nervous shock occasioned by negligence and producing physical injury to the suffer gives a cause of action. There is, I am inclined to think, at least one limitation. The shock, where it operates through the mind, must be a shock which arises from a reasonable fear of immediate personal injury to oneself. A. has, I conceive, no legal duty not to shock B.'s nerves by exhibition of negligence toward C., or towards the property of B. or C." Dulieu v. White \& Sons, [1901] 2 K.B. 669, 675. Plaintiff, behind the bar in her husband's public house, had suffered severe shock when defendant negligently drove his van into the room and frightened her. The court found a breach of duty in defendant's unlawful invasion of the house and allowed recovery without impact.

43 Hambrook v. Stokes Bros., [1925] I K.B. at 151, 157; Bowman v. Williams, 164 Md. at $402-03,165$ A. at 184. 
logic in allowing recovery by a man who said he had worried about his own safety while denying it to another who said he was worried about his children. ${ }^{44}$

The artificiality of the Hambrook-Bowman concept is apparent. If physical risk to the plaintiff is the real concern, only fear which results from that risk should be actionable, and thus Kennedy, J. was correct. But the real concern is not physical risk, but rather any kind of fear caused by the defendant's actions. The zone of physical risk in reality serves only as a limitation.

Although the rationale would have been different if the courts had used a negligence approach, the results would have been the same. Shock is most expected when the victim's life is in danger, regardless of whether the lives of close relatives are also threatened. Addition of the latter threat just increases the likelihood of harm. And, by definition, it is when the plaintiff is in the zone of physical risk that his life is in danger. The extension of liability to cover this zone was a logical one, even within the confines of a negligence theory.

Bystander cases. The third category, in which the plaintiff is a bystander, is currently in a state of flux, with recovery most often denied. It is also the category in which the courts have begun to use the language of foreseeability and to concentrate upon the possibility of emotional rather than physical harm.

The first important British case to follow Hambrook was Owens $v$. Liverpool Corporation, ${ }^{45}$ in which the plaintiffs allegedly suffered shock after seeing the defendant's tramcar run into a hearse carrying the body of their deceased relative. The court, not questioning the existence of significant injury, allowed recovery despite the fact that the tramcar had never come close to hitting the plaintiffs and that there had been no breach of duty as to physical safety upon which the plaintiffs could rely. Any breach must have been against the funeral company, which owned the damaged hearse.

Possibly Owens can be narrowly explained by the fact that the law has often given burials a special form of protection. ${ }^{46}$ Otherwise, its implications are very broad. In any event, these implications were not accepted.

Two classic American cases, Waube v. Warrington ${ }^{47}$ and Resavage

44 In practice, defendants, under "Kennedy, J.'s limitation," would try to get plaintiffs to talk themselves out of court by testifying to an altruistic worry for the safety of their children rather than a selfish worry for themselves.

45 [1939] 1 K.B. 394 (1938).

46 See Prosser 349 nn.69-72.

47216 Wis. 603, 258 N.W. 497 (1935). 
v. Davies, ${ }^{48}$ concerned mothers who, although at a safe distance from the accident, allegedly suffered shock as a result of watching the defendants run over their children. Both courts held to the old "zone of physical risk" analysis to deny recovery. Although the defendants had breached a duty to the children when they struck them, they had breached no duty to the mothers, who were out of the way. The Waube case relied upon Palsgraf $4^{49}$ as authority; Resavage followed Waube. Resavage also distinguished Hambrook and Bowman on the ground that the defendants had breached a duty to the plaintiffs in those cases by subjecting them to the risk of physical injury. ${ }^{50}$

In Bourhill v. Young, ${ }^{51}$ the British court took a different tack. It accepted the possibility of recovery in a case in which there was no physical risk to the plaintiff and then proceeded to limit it. The case involved a fishwife who had suffered shock upon seeing a motorcycle rider crash into a car forty feet from where she stood, though she was never in danger of being hit. She had a stillborn baby a month later as a result. In denying liability, the court stated that a person breaches a duty of care toward another only when it is foreseeable that a normal individual might be harmed by his action. One could not expect a normal person, even a pregnant one, standing and watching the motorcycle rider in this case to suffer shock upon seeing his accident. ${ }^{2}$

King v. Phillips ${ }^{53}$ limited Owens even further. A mother became hysterical when she heard a scream and saw her child's bicycle underneath a taxi. As in Waube and Resavage, the court denied recovery, but unlike the Waube and Resavage courts, it did so on foreseeability grounds. Like the Bourhill court, it accepted the argument that the relevant possibility was of emotional, and not physical, injury. It then found that possibility quite remote. ${ }^{54}$

The current state of British law is cloudy. An early move toward

48199 Md. 479, 86 A.2d 879 (1952).

49 Palsgraf v. Long Island R.R., 248 N.Y. 339, 162 N.E. 99 (1928). Plaintiff was injured while standing on a railroad platform. An explosion, which occurred when the defendant's servants pushed a man onto a departing train and caused him to drop a bag of fireworks, knocked a weight scale down onto her. The New York Court of Appeals, speaking through Cardozo, J., refused to hold the defendant railroad liable for her injury, finding that its servants' conduct might have been negligent toward the passenger, but not toward her. She was outside the circle of risk created by the servants' negligent conduct.

50 See note 44 and accompanying text supra.

51 [1943] A.C. 92 (1942).

52 See Lord Porter's discussion of normality and the duty drivers owe frequenters of the street. Id. at 117.

53 [1953] 1 Q.B. 429.

54 For further discussion, see Goodhart, Emotional Shock and the Unimaginative Taxicab Driver, 69 L.Q.R. 347 (1953). 
letting bystanders recover in Dooley $v$. Cammell Laird of Co. ${ }^{55}$ was seemingly rejected by King $v$. Phillips. Yet a recent but little noticed decision, Boardman $v$. Sanderson, ${ }^{56}$ followed Dooley. The plaintiff and his son were passengers in defendant's car when they stopped at a gas station. The plaintiff, at the defendant's request, went inside to pay the bill, while his son played outside. Defendant, not noticing where the boy was playing, started up and backed into him. The plaintiff was allowed to recover for nervous shock which resulted when he heard his son's screams and rushed to his aid. The court emphasized the close relation of the plaintiff to the victim and the fact that the defendant knew the plaintiff was on the premises.

It is arguable that emotional harm was more "foreseeable" in Boardman than in King v. Phillips, since, in the former, the defendant had reason to know that the plaintiff would observe the accident. The utility of such a distinction is questionable, however. There is a fair likelihood that a relative will witness any neighborhood accident. The actions of the defendant in King were just as careless as those in Boardman and the reaction of the mother just as normal.

American courts have not been quick to follow. Certainly, as a general rule, Waube and Resavage remain good authority, and bystanders cannot recover. ${ }^{57}$ The view of the learned judge in Mason $v$. Gray, ${ }^{58}$ however, indicates that some courts may rethink their policy as the equities of particular cases cry for change.

Absence from scene of impact. Little or no law has developed in the fourth category. "Emotional harm" resulting from hearing or reading about an accident is highly unlikely, and traditional rules of law would preclude recovery. ${ }^{59}$ However, as more jurisdictions accept a negligence approach to emotional harm, cases in this category may be litigated.

Inherent in the negligence approach are factors which should operate to prevent overexpansion of liability in this area: the requirement

55 [1951] 1 Lloyd's Rep. 271. King $v$. Phillips was decided two years later. The plaintiff in Dooley was a crane operator. Due to the defendant's carelessness, the rope with which the crane moved its load broke, dumping the load into the hold of a ship where men were working. The plaintiff suffered shock from witnessing the danger to the men below. Though in no danger of sustaining physical harm himself, he recovered, the court holding that the defendant should have foreseen the possibility of emotional harm to him if the rope broke.

56 [1964] 1 W.L.R. 1317. For discussion, see Dworkin, An Unreported Nervous Shock Decision, 25 MOD. L. REv. 353 (1962). The case was affirmed on appeal after Dworkin wrote his article.

57 Prosser 352-53.

58 See text accompanying notes 16-20 supra.

50 By definition of this category, the plaintiff is not in the zone of physical risk. See 2 HARPER \& JAMES 1037 n.30. 
that "emotional harm," not mere grief or upset, have been suffered, and the use of the normality standard..$^{\circ 0}$

A current case, yet to be tried, provides an interesting example of the type of action which may arise.61 The plaintiff, upon prescription by her doctor, began using one of the drugs which has recently been found to cause harmful side effects in some users. After reading about these adverse effects, the plaintiff began to imagine that she was suffering from some of them. In reality, she was physically healthy, but there was no question that she had suffered a nervous breakdown as a result of her worrying. The drug manufacturer has repeatedly been found guilty of negligence in testing the drug. Can the plaintiff use this negligence to recover for her emotional difficulties?

Under a negligence approach, she would have a cause of action. The central issue would be whether or not the manufacturer's carelessness created a substantial and unreasonable risk of emotional harm to a normal person who had used the drug and read about its problems without actually suffering them. At best, this is extremely doubtful.

Defying categorization, though reminiscent of Owens $v$. Liverpool Corporation, the funeral procession case, is the set of cases which involve grief and other mental anguish resulting from the negligent failure of a telegraph company to deliver a message of illness or death. A number of courts have allowed recovery, either in contract or tort, provided the telegraph company knew or had reason to know of the character of the message, on the grounds that in such a situation acute emotional distress is foreseeable and the risk of mental anguish is unreasonable. ${ }^{62}$ These cases have accepted by implication the negligence approach this comment has discussed.

Contributing to the basic similarity in results between the negligence and traditional approaches is their parallel treatment of the level of injury required before a plaintiff can have a valid cause of action. Under the negligence approach, this comment has stipulated "emotional harm"-an emotional injury serious enough to require medical

60 Compare the result in intentional tort cases, where a plaintiff was allowed to recover after becoming ill when defendant threatened her husband with a pistol, Jeppsen v. Jensen, 47 Utah 536, 155 P. 429 (1916), and a plaintiff similarly recovered when defendant, as a practical joke, told her that her husband had been injured in a gruesome accident, Wilkinson v. Downton, [1897] 2 Q.B. 57.

61 The author would like to thank James A. Hourihan of Hogan \& Hartson, Washington, D.C., for suggesting this hypothetical, the facts of which are slightly altered. In the actual case the plaintiff had a history of psychological difficulties.

62 See 1 Harper \& James 672-73; Prosser 348-49. Prosser states that the federal rule, covering interstate transmission of messages, and the greater number of state decisions are now to the contrary. 
attention. ${ }^{63}$ The Restatement, representing the traditional view, speaks of "illness or other bodily harm," 64 but its meaning is roughly the same. ${ }^{65}$ In contrast is the Restatement concept of "emotional distress," 66 for the negligent infliction of which there is no recovery under either theory. ${ }^{67}$

III

Heretofore, the positive aspects of a negligence approach to emotional torts have been emphasized. Adoption of such an approach would have significant consequences in two areas. One is the case in which physical negligence is present, but emotional negligence is notthe Williamson and Kaufman cases. Here, under a negligence approach, and in contrast to the traditional rules, the defendant is not liable for emotional harm unconnected to the physical injuries. The other is the case in which emotional negligence is present while physical negligence is not-certain bystander situations. Under the negligence approach, the defendant may be liable, while under traditional theories, he is not. For the vast number of other cases, the results should be the same.

But there are negative aspects also. Because "emotional harm" is a more fluid concept than "physical harm," the requisite proof of emotional negligence is more complicated. Physical harm is observable in most situations, while emotional harm is not. There is a consensus on what physical harm is, but psychiatrists, not to mention laymen, might strongly disagree as to what emotional troubles should prompt the sufferer to seek medical aid.88 Finally, "normality" is easier to define in physical than in emotional terms.

63 See text accompanying notes 24-28 supra.

64 RESTATEMENT (SECOND) OF TORTS \& 306 (1965).

65 Id. $\S 46$, comment $k$, where "bodily harm" is described as shock or illness. It is contrasted to "emotional distress," which "includes all highly unpleasant mental reactions, such as fright, horror, grief, shame, humiliation, embarrassment, anger, chagrin, disappointment, worry, and nausea." Id. $\$ 46$, comment $j$.

66 See note 65 supra.

67 RESTATEMENT (SECOND) OF TORTS $\$ 306$ (1965). It should be noted that if the defendant acted intentionally or recklessly, the plaintiff need not have suffered bodily harm to have a cause of action. Severe emotional distress is enough. Id. $\$ 46$.

68 Negligence theory contains a pitfall if only abnormal people suffer "emotional harm" as a result of being frightened or angered by the negligent conduct of others. Then no one could recover, for no careless conduct could be found to create a substantial and unreasonable risk of emotional harm to a normal person in the plaintiff's position.

John Havard has argued that fear does not cause lasting damage in the normal individual. Havard, supra note 3, at 482. Smith has pointed out that most emotional injury cases involve idiosyncratic victims. Smith, supra note 4 , at 282. Do these statements cast doubt upon the efficacy of a negligence approach?

As to Havard, there need not be "lasting damage" for there to be emotional harm, as it has been defined. As to Smith, the reported cases do not present a representative 
The relative fluidity and vagueness of emotional negligence concepts lead to a further and more important problem. The jury reaches the question of the breadth of the zone of emotional risk in the particular case as a factual determination, and since the standards with which it must work are vague, it retains a greater decree of discretion than under the artificial limitations of the traditional approaches.

This discretion can be restricted in several ways. Courts will want to formulate a set of jury instructions which emphasize and explain the concepts of "emotional harm," risk, and normality. Counsel will want to introduce expert testimony on the probable reactions of a normal person, given all the variables in the accident situation.

Still, there is the danger that an individual jury may become overly sympathetic. As this comment has defined it, a properly operating negligence approach should initially be expected to expand liability only to those cases which involve emotional injuries to a bystander in close relation to an accident victim. ${ }^{69}$ Of course, if scientific evidence becomes available showing that risk to other bystanders or certain nonbystanders is sufficiently great in certain situations, this estimate will have to be revised. Until that time, appellate courts may be justified in imposing Dean Prosser's closely related bystander limitation.70

With this last restraint on the jury, the advantages of a negligence approach far outweigh its disadvantages. The changes it would produce are both practically and theoretically desirable, yet would not represent too great a break with past law. In this author's view, both British and American courts are slowly moving toward just such a standard.

sample of emotional injury victims. Litigation is expensive, and relatively few emotional injury victims recover. So, unless the injury has led to expensive psychiatrist's bills or a complete disruption of the victim's life pattern, it is raxely worth the gamble to sue. Since idiosyncratic victims suffer the most serious injuries, they bring a disproportionate number of the cases. The doubt must remain unanswered until the system has had more experience with victims who may be classified as normal.

69 Theoretically, a negligence approach reduces liability more than it extends it. Under traditional tests, every auto accident victim has a cause of action for any emotional injuries he receives, so long as he can prove defendant's negligence toward his physical safety. Under the negligence approach here advocated, he must prove emotional negligence also.

Practically, this difference has little effect, since most accident victims do not suffer emotional injuries which are separate from their physicial harm, and thus do not sue on a separate cause of action for it. Williamson and Kaufman are the exceptions.

70 Prosser 354. See note 34 supra. 